The 49th Annual Conference of the International Association of School Librarianship

The 24th International Forum on Research on School Librarianship

July $12-16,2021$

Fadekemi O. Oyewusi, Margaret O. Abimbola

East Carolina University, University of Ibadan

m.abimbola10@gmail.com

\title{
Bibliotherapy Intervention for Combating Aliteracy in High Schools: School Librarians to the Rescue
}

\begin{abstract}
Aliteracy, the lack of interest in reading by capable readers had been observed to be prevalent among high school students and this has been a source of concern for education stakeholders. This study examined the remedial influence of bibliotherapy in reducing aliteracy among high school students in Ilesa, southwest Nigeria. The objectives of the study were to discuss the prevalence of aliteracy and examine the importance of reading among the high school students as well as describe the remedial impact of bibliotherapy in combating aliteracy among the high school students. All the 18 participants who identified as aliterates were exposed to Focus Group Discussion (FGD) which involved bibliotherapy. Content analysis was employed to analyse the responses of the participants to self-designed questions after the bibliotherapy sessions. The participants affirmed that exposure to bibliotherapy sessions helped in reducing aliteracy irrespective of their gender and that they needed the support of their parents to sustain an appropriate attitude to reading. Therefore, school librarians with the knowledge of bibliotherapy could be of help in reducing aliteracy among the high school students.
\end{abstract}

Keywords: Nigeria, bibliotherapy, reading, aliteracy

\section{Introduction}

Aliteracy is the term used to describe the lack of interest in voluntary and involuntary reading by capable readers (Wells, 2012). Students with the tendency of aliteracy are referred to as aliterates and aliterates are identified by their reading attitude and reading behaviour. Aliterates exhibit negative feeling for reading and as such, negative reading attitudes which include the feelings that reading is burdensome, tiresome, time-consuming and not rewarding. Aliterates manifest negative reading behaviour which is depicted by faking the act of reading when it is demanded of them, finding faults in all genres of books and authors and having a feeling of discomfort when it is required (Stearn, 2018). Apart from the negative reading attitude and negative reading behaviour that they exhibit, aliterates can be identified by school librarians in the school system by the intensity of motivation they have for reading, the type of texts read and importance attached to reading. Aliterates exhibit low intensity of motivation when it comes to reading and are usually put off by long texts that are not of interest to them, being only interested in short texts of interest. Motivation could be intrinsic or extrinsic and denotes the internal and external 
factors which could provoke the desire to be continually committed to a course; it is the willingness to wield effort towards the realisation of a goal.

Intrinsic motivation occurs when an individual is motivated by internal factors to perform a certain behaviour while extrinsic motivation occurs when an individual is motivated by external factors to perform a certain behaviour (Lai, 2011). Aliterates are barely motivated either by internal or external factors to read, they exhibit low intensity of motivation to read any genre of books because they attach little or no value to reading. Aliterates can be recognized by the school librarians by the kind of importance attached to reading, as they attach little or no importance to reading.

Basically, there are two forms of aliteracy which are functional aliteracy and conditional aliteracy. Functional aliteracy occurs when a student has poor reading skills, finds reading an onerous task and boring, does little or no reading for entertainment and evades any kind of reading if possible; while conditional aliteracy occurs when a student is made an aliterate by being exposed to certain conditions that are not encouraging (Sweeney, 2003), such as lack of functional libraries with qualified personnel, lack of parental support and involvement in reading and associated activities. This involves non-availability of reading space, books and other reading materials in the home, lack of positive and exemplary models of reading from parents, siblings, peers and teachers. All could lead to aliteracy among high school students.

\section{Statement of the Research Problem}

Aliteracy is becoming prevalent among high school students in Nigeria and if the menace is not controlled, the attainment of SGD-4, which is quality education by the year 2030, will be an illusion as there cannot be quality education where reading is not given the attention it deserves. High school students who are apathetic to reading stand the risk of becoming complacent adults who instead of contributing to societal development become less productive and creative thereby unable to contribute to the progress of the nation.

Factors such as lack of functional and well-equipped school libraries, rigid curriculum and lack of reading teachers had been judged to be responsible for the thriving of aliteracy among high school students. Its consequences include: examination malpractices, poor academic performances, poor communication skills, as well as lack of creativity and innovation. The establishment of well-equipped, adequately staffed school and public libraries and media centres, establishment of reading clubs, and role modeling in reading by parents and teachers are some of the ways suggested to tackle literacy in previous studies.

The researcher is not aware of any study that employed bibliotherapy to reduce aliteracy among the high school students in Ilesa, Osun State. This study attempted to fill this gap by providing 
empirical information on the effect of bibliotherapy to reduce aliteracy among high school students in Osun State, Nigeria.

\section{Objectives of the Study}

The study seeks to discuss bibliotherapy intervention as a remedy to combat aliteracy among high school students in Nigeria. The specific objectives of the study are:

- To discuss the spate of aliteracy among high school students in Ilesa, Southwest Nigeria;

- To examine the importance of reading to high school students in Ilesa, Southwest Nigeria;

- To describe bibliotherapy intervention as a remedy for aliteracy among high school students in Ilesa, Southwest Nigeria.

\section{Literature Review}

\section{Aliteracy and High school Students}

Aliteracy occurs when an individual who has the ability to read does not have interest in doing so, the paradox of being able to read but choosing not to read. The difference between illiterates and aliterates is that whereas illiterates cannot read because they do not have the ability to do so, aliterates have the ability to read but they make a choice not to read. Aliteracy, therefore, is the choice made by capable readers not to read when they have the ability to do so and not inability to read.

Boorstin, the Librarian of the Library of Congress, also acknowledged the decline in the reading habits of Americans in 1984 and referred to it as aliteracy as he observed that fewer American citizens were actively involved in reading (Abimbola \& Adeoye, 2013). Aliteracy in any community is capable of threatening the reading culture of such a community, when either the young, old or both in a community are dispirited towards reading. Not only will the culture of reading be endangered, the development of such a community will also be endangered.

Several attempts had been made in previous studies to confirm the menace of aliteracy among different groups of students. Beers (1996), one of the foremost researchers in the study of aliteracy among adolescents, described aliteracy as the ability to read but an indifference and boredom to reading for academic and enrichment purposes. Aliteracy happens when persons who have the ability to read are not passionate about reading but rather see reading as a burden. High school students are supposed to be positively inclined to reading and find pleasure in it, but when reading is perceived as being burdensome, time consuming and unprofitable, aliteracy has set in.

According to Vanslyke-Briggs (2011), aliteracy arises when students who are capable of reading make the decision not to read. However, where aliteracy occurs, individuals who are literate will only be able to perform at negligible levels of literacy, thereby impeding them from functioning 
effectively at their full potential. An attitude of consistent abhorrence of reading by high school students who are capable of reading owing to lack of interest becomes a negative reading habit, and indulgence in such habits of evading and dodging reading is capable of making such students to be near illiterates who cannot read.

Sweeney (2003) identified two forms of aliteracy which are functional and conditional aliteracy. Functional aliteracy depicts a state of having poor reading skills, low motivation for reading, finding reading strenuous, avoiding any kind of reading including reading for entertainment and pleasure. Reading skills help high school students to identify simple ideas presented in texts, appraise the texts and relate the texts to circumstances around. Developing and sustaining good reading skills by high school students makes reading become meaningful, enjoyable and stories in the books easy to relate to whereas poor reading skills make reading laborious. Reading motivation has to do with what motivates high school students to read which could be intrinsic or extrinsic motivation.

Intrinsic motivation has to do with an individual doing something due to special interest in such a thing while extrinsic motivation refers to a person doing something to prevent the consequence of not doing it. High school students need the two types of motivation for the important roles they play in nurturing the love of reading because reading does not come easy for students with low motivation for reading. High school students who are apathetic to reading avoid any kind of reading directly or indirectly by finding excuses for doing so. Thus, functional aliteracy has to do with the reading skills, reading motivation, reading interest and reading preference of the aliterates. High school students who are functional aliterates display poor reading skills, low reading motivation with poor reading interest and reading preferences.

Conditional aliteracy on the other hand happens when students are made aliterates due to certain unfavourable conditions they are being exposed to. Conditional aliterates may possess reading skills and may be capable of being able to read different types of reading materials with comprehension but may not make a choice towards reading due to certain unfavourable conditions in which they find themselves. Certain conditions such as shortages or lack of various books of interest at home and in the school, lack of school libraries, homes that are not conducive for reading and lack of role models in reading may lead to apathy to reading. Thus, such high school students are made aliterates not by choice but by the negative conditions that do not favour reading surrounding them.

Both forms of aliteracy are detrimental to students because functional aliteracy is capable of making the affected students develop a lack of interest in reading most genres of books that are supposed to be beneficial to them as a result of poor reading skills, low motivation, poor reading interest and poor reading preference. Conditional aliteracy could limit the potentials of the conditional aliterates if the conditions surrounding such students in the home and at school are 
not conducive for reading. High school students should be encouraged to make time for reading, no matter the conditions they are exposed to in the schools and at homes.

Different factors had been judged to be responsible for aliteracy among high school students. Some high students seem not to be excited by the ideas offered in books but rather choose to experience life directly instead of through reading and prefer to watch events on the screen rather than reading about them on the pages of books. Others see reading as an extended means of receiving information and as such not preferable as it does not offer the kind of pleasure obtainable by watching movies and the social media. Some other students find it difficult to sit still long enough to read for an extended period of time

Persistent pressure from homes and schools to read, especially for academic success, may not be productive for some high school students because many of the high school students are adolescents who have the tendency to resist pressure to engage in certain things including reading. Adolescents often prefer to do things at their pace and the readiness to engage in certain actions usually depends on the interest possessed in such, rather than external pressure from parents or teachers (Abimbola \& Adeoye, 2013).

The emphasis placed on academic accomplishment by schools and parents lead some high school students to have negative feelings towards reading because reading is not presented as an enjoyable activity which could be of advantage to the students in aspects of life other than academic accomplishment. Linking reading with accomplishment occasionally makes some high school students lose interest in reading as they are acquainted with some persons who had thrived in different chosen fields without much reading. Therefore, they do not see reading as the only means of achieving success (Wayne, 2003). Additionally, some high school students may grow up in homes where reading is not prioritised. Some parents of high school students failed to demonstrate modelling of reading at home and to such students reading is not important. Some high school students may consider reading to be unsociable and as such an act not to be delighted in (Aiza, Amelia, Affidah \& Siti, 2013; Ibrahim, 2013).

Though research on aliteracy are just evolving in Nigeria, the pervasiveness of aliteracy among high school students had been established in varied studies. Ilogho (2011) declared that high school students in Nigeria do not sometimes read for the love of it. Olufowobi and Makinde (2011) opined that students in Nigerian high schools do not find reading interesting and this has negative effects on diverse aspects of their lives including academic achievement. Most of those students find it difficult to analyse and grasp facts and comprehend examination questions.

Abimbola and Adeoye (2013) stated that boys and girls in Nigerian high schools involve themselves in activities that get them distracted from reading and these include negative use of computer, video games and the internet, uncontrolled interest in sports and unsupervised television viewing to mention a few. Involvement in all these activities makes high school 
students unable to create time for reading. Nwosu and Nnagha (2014) opined that Nigerian high school students will prefer to spend their leisure time to interact with the electronic and social media to gather information needed than to read to enhance knowledge.

Stating factors that may be responsible for aliteracy among high school students in Nigeria, Ilogho (2011) and Abimbola and Adeoye (2013) mentioned the instructional system which places much emphasis on rewards and outcome of academic achievement without taking the interest and needs of the students into cognisance. Other factors responsible for aliteracy include lack of passion and desire and motivation to read.

In Nigeria, aliteracy was discovered to be accountable for poor academic performances, examination malpractices and low literacy levels observed among high school students (Olufowobi \& Makinde 2011; Ilogho, 2011; Abimbola \& Adeoye, 2013; Nwosu \& Nnagha 2014).

Aliteracy could be reduced among high school students using bibliotherapy as a tool. Guided reading through the process of bibliotherapy with the help of teachers, librarians or school counselors may help the high school students to realise that aliteracy is not peculiar to them, this may aid them to be favourably disposed to the process of solving or coping with issues around aliteracy.

\section{Reading and High School Students}

Reading is an essential skill which high school students cannot do without. High school students ought to be exposed to a whole lot of information and ideas through reading of materials available in different formats. Through reading, the sharing of information and ideas with friends and associates becomes easy for secondary school students. Thus, communication becomes fluent once the right vocabularies are acquired and high school students are able to share information and ideas with confidence. The development of communication skills necessary to interact in society comes easy to the high school students through reading and sharing of facts and ideas (Oyewusi, 2016).

According to Garo (2014), high school students who spend more time reading would more likely be able to understand more complex texts, acquire more knowledge, and a greater variety of vocabulary than those who spend less time reading. Therefore, engaging in reading by high school students will kindle in them positive feelings and emotions, with a desire to learn new skills and become more knowledgeable not only about their immediate environment but the whole world. In order to improve their reading skills, high school students should be exposed to a wide range of reading materials such as books in both electronic and print format, magazines, fiction, non-fiction as well as comics among others. Reading a whole lot of materials encourages high school students in the development of positive reading attitudes which invariably enhances the advancement of good reading habits. 
The quantity of reading engaged in by high school students for pleasure, relaxation and academics has a significant role to play in determining academic accomplishment and personal enrichment. Evidently, engaging in intensive and extensive reading by high school students could enhance the chances of better performance at school and beyond school, thereby facilitating intellectual development (Fosudo, 2010). Reading encourages high school students to develop problem-solving skills as the process of solving problems based on what is learnt in the books is learnt. Furthermore, connecting reading to different aspects of life aids high school students to think abstractly about the texts and students should be encouraged to record their progress in reading because as this is done students would be able to gauge the time and efforts put into reading with the observed improvement brought about by reading. Through reading, high school students are able to have deeper thoughts about things happening around them and to proffer solutions without needless over-dependence on adults (Gray, 2016). Reading expands intellectual abilities of individuals because in-depth reading helps to nurture the mind and character of the students and it offers insights into human problems, attitudes and behaviour that help to mould character. Reading does not only widen the high school student's perception of life, it also affords them the means to explore their talents while learning about themselves and their environments as creativity blossoms in them (Sandas, 2007).

\section{Bibliotherapy for Aliteracy Among High School Students}

Bibliotherapy is the process of assisting individuals to overcome personal problems through the practice of guided reading. It is the process by which books are employed to help individuals resolve certain problems. The word bibliotherapy originates from the Greek words for book 'biblio' and healing 'therapia'. Samuel Crothers, an American Cleric, combined the two words (bibliotherapy) in 1916 to refer to healing through the reading of books (Pehrsson \& McMillen, 2007). Bibliotherapy can be described as a process by which persons experiencing personal problems may seek therapy (healing) through the reading of selected books in which the main characters went through precise or similar problems to the readers (Shechtman, 2009).

According to Norcross, Beutler, and Levant (2006) bibliotherapy is a process that involves cautiously prescribing books to persons with specific problems with the aim of guiding such individuals to make use of the lessons learned from the process, with the treatment being followed up by occasional meetings to discuss the book. Bibliotherapy involves the systematic usage of books to help people realise and solve specific problems which may range from physiological, psychological, mental or emotional problems. Bibliotherapy is said to be systematic in the sense that it involves careful preparations on the part of the facilitator which include the selection of age appropriate books and the inclusion of effective discussion and activities (Fu, 2010; Henney \& Weckworth, 2012). It involves the process whose goal is to support individuals to come out of negative emotions related to some real-life problems through 
guided reading followed by individual or group discussion in a non-threatening environment (Montgomery, 2015).

Bibliotherapy encompasses some main stages which are identification, catharsis and insight. Through identification, the reader identifies with and relates to the character such that through the process of reading a book, the reader feels what the character felt, comprehends the problem the character went through and recognises the responses of the character to the problem. At the stage of catharsis, the reader has the tendency to be emotionally involved in the story and may release bottled-up feelings as he feels the pain experienced by the character thus seeing himself in the mirror of the character. At this stage, the reader comes to the realisation that he is not alone in his predicament as he sees someone in the literature who has gone through what he is going through and learns how to come out of the predicament the way it happened to the character in the book (Smith, 2014). Another important stage in the execution of bibliotherapy among secondary school students is universalisation. This is the stage at which the bleakness in the mind of the reader concerning his predicament is removed after undergoing the first three stages.

Bibliotherapy could be used by teachers, librarians and school counselors to help aliterates among the high school students to realise that aliteracy is not peculiar to them. This could be of help in making connections between themselves and characters from the relevant books, thereby guiding them in the process of solving or coping with issues around aliteracy.

In the application of bibliotherapy to deal with aliteracy among high school students, pertinent issues such as the needs of the students concerned, selection of appropriate book(s) to resolve the identified need should be put into consideration while aliterates among the students should be properly identified. The choice of appropriate book is vital to the outcome of bibliotherapy and two types of reading materials, didactic and imaginative texts are usually used (Silverberg, 2003).

The didactic texts are instructional and educational materials comparable to textbooks used in the traditional educational process which involve texts that are intentionally written to address some specific problems. They are also referred to as non-fiction while imaginative texts are books that dramatically present human behaviour through fiction, drama, and poetry among others. The effectiveness of bibliotherapy to fulfil the purpose for which it is being carried out, entails discussion and follow up which should have been properly planned ahead before the beginning of bibliotherapy. Discussion and follow up could be carried out by retelling the stories, detailed discussion of the book and leading the students to arrive at a productive decision that will lead to possible solution to the problem identified (Mclynte, 2004; Elder, 2012). The goals of bibliotherapy comprise providing information and understanding of the problem, initiating discussion about the problem identified, communicating new ideologies and attitudes, creating consciousness that others have dealt with comparable problems and finally to offer solutions to 
the problem (Ward et al, 2016). There is the predisposition for aliterates in high schools not to be aware of their conditions, because they are aware of their lack of interest in reading but they are not mindful of its consequence on academic accomplishment and future careers. Bibliotherapy permits the aliterates to freely discuss feelings about reading, views on aliteracy and if there are misconceptions about reading they have been nursing; bibliotherapy gives them the occasion to discuss such without bias. When bibliotherapy is properly carried out among the aliterates, developing a new attitude to reading comes easily to them. High school students' struggles with reading and difficulties hindering them from developing good reading habits would be freely discussed, and the decision to have a changed attitude to reading is made without coercion. If appropriately administered among the high school students, bibliotherapy may help them to grow problem solving skills, survival skills, social and emotional fitness, and enhanced academic accomplishments.

Through the process of matching students' circumstances with appropriate literature, students are provided with an opportunity to appreciate the fact that others have been confronted with comparable struggles they are presently struggling with, thus, acquire the skills to handle or modify their behaviour either by copying the activities of characters in the story or by evolving solutions peculiar to the problem (Gregory \& Vessey, 2004; Jackson, 2016). While selecting books to be used as bibliotherapy tools to address aliteracy among high school students, the suitability of the book to the students' age, gender, maturity and background should be given consideration by the facilitators and in some cases, bibliotherapy may have to be used with other forms of intervention programmes (Dirks, 2010; Goddard 2011). Ilogho (2011) also opined that reading relevant books during the bibliotherapy process could stir up students' motivation and incite a drive for academic achievement in Nigeria. In an attempt to help the affected high school students out of aliteracy, enough time should be given to group and individual discussion of the selected texts as well as the periodic appraisal of the intervention programme.

The effectiveness of bibliotherapy in reducing aliteracy among the high school students may not necessarily depend on the gender of the aliterates once the appropriate books are selected and well-directed discussion is involved. Thus, irrespective of gender, bibliotherapy could efficiently reduce aliteracy among high school students as long as the appropriate books are chosen for the exercise with guided discussions. According to Ranjabar and Faghbori (2016) books with genuine situations that could be easily related to by the students should be chosen by the facilitator and once this is done, the students may respond with desirable changes irrespective of the gender. Elder (2012) also confirmed that discussion and follow up activities during bibliotherapy could assist the students to arrive at a beneficial decision which is able to lead them to a definite resolution of the problem.

Guided reading of suitable books with guided discussion through the process of bibliotherapy, if combined with parental support in reading, could be effective in reducing aliteracy among the 
high school students. Camp (2015) asserted that each adolescent is unique with divergent problems such as background, poverty, and relationships which have the tendency to affect their attitude to reading; but, if bibliotherapy is carried out with parental support, aliteracy could be reduced among high school students. According to Smiedt (2015), while bibliotherapy has the tendency to improve high school students' self-confidence and offer a mirror for reflection and room for thoughtful expression, parents have a substantial role to play in the development and sustenance of the right attitude to reading.

\section{Methodology}

For the purpose of this study, aliterates were identified through a 10 item self-assessment survey tagged "Aliteracy Initial Survey" which was designed using four constructs regarded as aliteracy indicators. The constructs used were: motivation to read, types of text read, importance attached to reading, and reading skills. A Likert scale of Very True of Me (VTM), Almost True of Me (ATM), Fairly True of Me (FTM) and Not True of Me (NTM) was used. Participants with scores of $70 \%$ and above were used for the study since Koriat and Bjork (2006) confirmed that students have the predisposition to overestimate their academic activities of which reading is a significant one. All 18 high school students who identified as aliterates were used for the study. The participants were exposed to Focus Group Discussion (FGD) and this involved the use of two books which are "The Big Boy" by Deborah Sijuwade and Segun Ogunsanya and "You Have a Brain" by Ben Carson for bibliotherapy sessions with guided discussion for a period of one hour for eight weeks.

\section{Discussion of Findings}

The study focused on aliterates in the high schools in Ilesa, Southwest, Nigeria. These students were identified as having all the traits of aliteracy such as poor reading skills, negative reading attitude, negative reading behavior, low motivation for reading and low reading ability among others. To start with, the researcher obtained approval to carry out the study in the selected schools in Ilesa from the Permanent Secretary Osun State Ministry of Education (see Appendix II), consent to carry out the study was then obtained from the principals of the selected schools. The participants who identified as aliterates as earlier stated were briefed about the essence of the study after which the research commenced.

\section{Why did you identify as aliterates?}

All the high school students involved in the study stated that though they had ability to read, they were not enthusiastic about reading and had little or no interest in reading.

\section{What is the effect of bibliotherapy on aliteracy?}

FGD participants were asked to describe the effect of bibliotherapy on the aliteracy exhibited by them. The participants stated that exposure to bibliotherapy affected their disposition to reading. In their words: 
Bibliotherapy helps us to develop good reading habits as we were able to reduce the time spent in playing and other frivolous activities and devote more time to reading. It opens our eyes to see the need to change our attitude to reading as we understand the implication of aliteracy.

\section{How does gender affect aliteracy among high school students?}

The participants were asked if they were aliterates because of their gender and they responded that gender has nothing to do with being aliterates. In their statement:

Gender has nothing to do with being an aliterate. I was not an aliterate because of my gender. I became an aliterate because of the wrong choice I made regarding reading and not because of my gender.

How does parental involvement affect aliteracy and bibliotherapy in high school students? Participants are of the opinion that parents have roles to play in averting aliteracy among high school students. They affirmed that their parents offer support in academic activities but not necessarily in reading. In the words of the participants:

Even though our parents do what they can to support us in our academic activities, not much is being done in supporting us specifically in reading. Our reading habits could have been better if relevant textbooks and recreational texts are purchased as more time is allowed to read at home and the home is made conducive and comfortable for reading.

According to the respondents:

With bibliotherapy sessions that we have been exposed to, if our parents can give us necessary support in reading by getting us novels, textbooks and asking us questions about our reading activities, our reading habits will greatly improve.

\section{Discussion of Findings}

The FGD study participants are of the opinion that bibliotherapy sessions had gone a long way in changing their perception about reading. The results of the study agreed with the report of Ilogho (2011) that reading appropriate books through the process of bibliotherapy inspires high school students in Nigeria and incites a drive for academic achievement. They all agreed that before the start of bibliotherapy, they had a negative reading attitude and reading behaviour with poor reading skills, but going through the stories in the selected books opened their eyes to the consequences of aliteracy which informed their decision to imbibe a positive reading attitude and behaviour. Therefore, having passed through the first three stages of identification, catharsis and insight, the students developed a sense of normalcy and optimism which is in agreement with the assertion of Montgomery (2015) that guided reading supported with group or individual counseling in a non-threatening setting could help high school students realise that their aliteracy is not peculiar to them. The realisation makes high school students be ready to move beyond the 
feelings of contentment and self-satisfaction thus supporting the statement of Gordon (2015) that students at the point of universalisation drop the sense of loneliness and develop actions that could help in problem solving.

When asked if the responses shown during bibliotherapy sessions have anything to do with gender, the participants responded that the positive response to bibliotherapy intervention has nothing to do with gender. The FGD participants were of the opinion that aliteracy is a choice made not to be interested in reading and has nothing to do with the gender of the students. The participants believed that the choice to jettison aliteracy has nothing to do with being a male or female, rather it has to do with response to bibliotherapy sessions. This supports the assertion of Elder (2012) that discussion and follow up activities in bibliotherapy are capable of aiding the students to arrive at a constructive decision which is capable of leading them to a possible solution to the identified problem. Therefore, the finding of the study confirms that the effectiveness of bibliotherapy in reducing aliteracy depends largely on the relevance and appropriateness of the reading materials and discussion by the facilitator and not necessarily the gender of the students.

When asked if the combination of bibliotherapy and parental involvement in reading could have helped them in becoming good readers, the participants responded that the bibliotherapy sessions they went through have the impact of turning them from aliterates to avid readers, but there is need for the support of parents to sustain the positive reading attitude they have developed. This confirms the assertion of Shechtman (2009) that the significance of high-quality literature appropriate to the age, background and mental ability of students in applying bibliotherapy cannot be overemphasized. Once the appropriate book is selected and accompanied by well-guided discussion capable of bringing an aliterate to the point of making informed decisions, gender and parental involvement may not be barriers to the expected change in behaviour. Nevertheless, parents should support the school librarians and other relevant stakeholders in reducing aliteracy among the high school students.

\section{Implications and Conclusions}

The implication of aliteracy is too critical to gloss over; therefore, the findings of this study revealed that bibliotherapy can be employed by school librarians to combat aliteracy. The findings of the study showed that gender does not make a student an aliterate. A student in high school could be an aliterate or not, irrespective of whether he is a male or she is a female. The findings of the study also indicated that bibliotherapy combined with parental support could go a long way in dealing with aliteracy among high school students.

Aliterates among high school students should be identified as early as possible. School librarians should be trained and equipped to offer bibliotherapy services to students, especially the aliterates. Reading materials in different formats that will arouse the interest of high school 
students in reading should be made accessible in the school libraries and fiction with the stories of aliterates whose reading attitude later turned from negative to positive, non-fiction with focus on benefits of developing positive attitude to reading should be provided in the school libraries and made accessible to all categories of students, particularly the aliterates. School librarians should work with teachers and parents to inculcate and maintain the love of reading in high school students. Ultimately, school librarians with the knowledge of administering bibliotherapy could provide a solution to the menace of aliteracy among high school students in Nigeria, thereby reducing it.

\section{Acknowledgement}

The authors appreciate the Permanent Secretary, Ministry of Education, Osun State who gave permission to carry out this research in the government owned high schools in Ilesa, Southwest, Nigeria. We are also sincerely thankful to the principals, vice-principals, teachers and students of the participating schools.

\section{References}

Abimbola, M. O. \& Adeoye, M. O. (2013). Tackling aliteracy in Nigerian secondary schools: A role for school libraries. PNLA Quarterly, 77(4), 50-63.

Aiza, J., Amelia, A., Affidah, M. \& Sahari, S. (2013). Students' reading practices and environment. Indonesian Journal of Applied Technology, 3(1), 187-193.

Beers, K. (1996). No time, no interest, no way: The three voices of alliterates. School Library Journal, 42(2), 30-33.

Camp, R. (2015). Perceptions of bibliotherapy: A survey of undergraduate students. [Master Thesis in special Education, Iowa State University]. https:// www.semanticscholar.org.

Dirks, K. L. (2010). Bibliotherapy for the inclusive elementary classroom. [Senior Honour Thesis, Eastern Michigan University[.

Elder, R. (2012). Healing reads. Bibliotherapy for the 21st century. https://inforpeople.org. Fosudo, S. (2010). Reading as path to success: A lecture delivered at the College Library Day. Adeniran Ogunsanya College of Education, Otto/Ijanikin, Lagos on February 24.

$\mathrm{Fu}, \mathrm{H}$. (2010). Coping with stress through bibliotherapy: The effect of Zhang Zi's fables for Taiwan college students. [Thesis, University of Hull]. https://www.rgus.ac.in.

Garo, L. (2014). Importance of reading fiction. Project. Educational Leadership and Human Development, Education. University of Central Missouri.

Goddard, A. T. (2011). Children's books for use in bibliotherapy. Journal of Paediatric Health Care, 25, 57-61.

Gray, K. (2016). Cognitive benefit of reading on children. Study.com. https://study.com/academy/lesson/cognitive-benefits-of-reading-on-children.html

Gregory, K. E., \& Vessey, J. A, (2004). Bibliotherapy: A strategy to help students with bullying. The Journal of School Nursing, 20(3), 127-133. https://doi.org/10.1177/10598405040200030201 
Henney, S. \& Weckworth S. (2012). Using children's books to address students' social and emotional concerns: A project. California State University. https://scholarworks.calstate.edu/downloads/hm50tr80w

Ibrahim, M. (2013). Reading culture: Its impact on secondary school students. Paper presented at a special lecture organised by the Department of English, Girls' College, Garko, Kano-Nigeria on March 3, 2013.

Ilogho, E. J. (2011). The rising population of aliterates in Nigerian schools: The roles of school libraries. Library Philosophy and Practice, 11. https:/digitalcommons.unl.edu/libphilprac/653/

Ilogho, E. J. (2011). Bibliotherapy: An option for enhancing students' motivation for academic achievement in Iganmode Grammar School and Grait International College, Ota, Ogun State. IFE PsychologIA, 19(2), 437-461. https://www.ajol.info/index.php/ifep/article/view/69588

Jackson, M. (2016). Bibliotherapy revisited: Issues in classroom management. Developing teachers' awareness and techniques to help children cope effectively with stressful situations. Guam: M-m mauleg publishing. https:/files.eric.ed.gov/fulltext/ED501535.pdf

Lai, E. (2011). Motivation: A literature review. Pearson Research Report. 1-44. http://images.pearsonassessments.com/images/tmrs/motivation_review_final.pdf

Mclyte, T. (2004). How to use psycho educational interventions: Bibliotherapy. Retrieved from https://www.behaviouradvisor.com.

Montgomery, P. \& Maunders K. (2015). The effectiveness of creative bibliotherapy for internalizing, externalizing and pro social behaviours in children: A systematic review. Children and Youth Services Review, 55, 37-47. https://doi.org/10.1016/j.childyouth.2015.05.010

Norcross, J. (2006). Integrating self-help into psychotherapy: 16 practical suggestions. Journal of Professional Psychology: Research and Practice, 37(6), 683-693.

Nwosu, M. D. \& Unagha. A. (2014). Aliteracy: Changing tide in the reading culture of students in Nigerian Secondary Schools. International Journal of Innovative Research in Engineering and Sciences, 12(3), 24-36.

Olufowobi O. \& Makinde, S. (2011). Aliteracy: A threat to educational development. Educational Research, 2(2), 824-827.

Oyewusi, F. O. R. (2016). Understanding the use of school library media centres. Ibadan: Stirling holdings. 171p.

Pehrsson, D. \& McMillen, P. (2007). Bibliotherapy: Overview and implications for counsellors. Professional Counselling Digest 2. https://digitalscholarship.unlv.edu/lib_articles/27/

Ranjbar, M. \& Faghfori S. (2016). A bibliotherapy session in progress. International Journal of English and Education, 5(4), 326-335. 
Shechtman, Z. (2009). Treating child and adolescent aggression through bibliotherapy. The Springer Series on Human Exceptionality. New York: Springer Science and Business Media. doi:10.1007/978-0-387-09745-9.

Silverberg, L. (2003). Bibliotherapy: The therapeutic use of didactic and literary text in treating, diagnosis, prevention and training. Journal of American Association of Osteopath, 103(3), 131-135. https://www.ncbi.nlm.nih.gov/pubmed.

Smiedt, J. (2015). Bibliotherapy: How books are great therapy. https:/www.wordpress.com.

Smith, S. (2014). Exploring the impact of bibliotherapy and family literacy bags on elementary students experiencing divorce. [Thesis, University of Central Florida] https://stars.library.ucf.edu/honorstheses1990-2015/1683

Stearns, C. (2018). Observing reading behaviour in students. https://www.study.com.

Sweeney P. (2003). Developing work instruction for alliterate users. American Society for Quality. 57th Annual Quality Congress, Kansas City of American Society for Quality Control: 93-106. https://www.explainer.com.

Vanslyke-Briggs, K. (2011). What went wrong: Middle school and aliteracy? North Carolina Middle School Association Journal, 26(1),1-13.

Ward, J. H., Bejarano, W. \& Allred, N. (2016). Reading for Recovery (R4R): Bibliotherapy for addictions. Substance Abuse Library and Information Studies, 3(1), 50-59. Retrieved from doi:10.7282/T3C82CPJ.

Wayne, B. (2011). A ladder to literacy: Sixth grade students create an approach that transformed alliterate adolescents into engaged readers. Middle School Journal, 43(2), 8-17.

Wells, C. (2012). Aliterate college students: Neglecting to read or engaging in a new literacy. [Master Thesis, University of Central Florida]. Electronic Theses and Dissertations, 2004-2019. 2170. https://stars.library.ucf.edu/etd/2170 